\title{
The Bronze Horseman: A St Petersburg Story
}

\author{
By A. S. Pushkin
}

Translated with a Commentary and Notes by John Dewey

www.tyutchev.org.uk 
John Dewey's verse translation of Alexander Pushkin's narrative poem The Bronze Horseman was shortlisted for the John Dryden Translation Prize 1996/7 and subsequently published in the journal Translation \& Literature (Volume 7, Part 1, 1998, pp. 59-71). The text of the translation is reproduced here by kind permission of Edinburgh University Press. The original publication may be accessed online at: http://www.euppublishing.com/doi/pdfplus/10.3366/tal.1998.7.1.59 


\section{The Bronze Horseman}

\section{PREFACE}

The events depicted in this story are based on fact. Details of the flood are taken from contemporary periodicals. Those interested may refer to the account given by V.N. Berkh. ${ }^{1}$

\section{INTRODUCTION}

A wave-swept shore, remote, forlorn:

Here stood $h e,{ }^{2}$ rapt in thought and drawn

To distant prospects. Broad and chartless

The river ran, along it borne

A lonely skiff, rough-hewn and artless.

Darker against the marshy green

Of moss-grown banks appeared some mean

Log huts: the poor Finns' habitation;

And forests which had never seen

The mist-veiled sun's illumination

Were live with whispers.

And he thought:

'From here the Swede is ill-protected:

A city on this site, to thwart

His purposes, shall be erected.

For here we may, by Nature blessed,

Cut through a window to the West ${ }^{[1]}$

And guard our seaboard with conviction.

At home in waters which had been 
Unknown, all flags shall here be seen, And we shall feast without restriction.'

A hundred years have passed. We see, Where swamp and forest stood but lately: The city, northern prodigy, Has risen, sumptuous and stately; Where once a humble Finnish lad Poor foster-child in Nature's keeping Alone upon the low banks had Oft cast his time-worn nets when reaping The waters' hidden harvest, - now Great towers and palaces endow The bustling banks with grace and splendour; From every corner of the earth Come vessels, jostling to berth At these rich wharves. Now, to defend her, Our city's banks are granite-cased;

Fair bridges interlace her waters;

And verdant parks bedeck those quarters

With which the islands have been graced.

So our young capital's aurora

Puts ancient Moscow in the shade, Just as a new tsaritsa's aura Must make the empress-mother fade. 3

O how I love you, Peter's daughter!4

Your aspect, graceful yet austere;

Nevá's 5 augustly flowing water

And granite banks: these I hold dear;

Your railings, finely ornamented;

Your pensive nights of moonless light

And lambent dusk, ${ }^{6}$ when I, contented,

Sit in my room and read and write 
Without a lamp, while in the nearly

Deserted streets huge buildings clearly

Loom up, asleep; and solar fire

Plays on the Admiralty spire; 7

And Dusk directly (as if plotting

To keep the golden skies alight)

Hands on the torch to Dawn, allotting

A brief half-hour to cheated Night. [2]

I love your winter, harsh and bracing:

The still air resonant with frost;

Girls' rosy cheeks; and sledges racing

By broad Nevá, now freely crossed;

And ballrooms: noisy, scintillating;

At junketings of single men

The glasses charged and coruscating,

And rum punch, flaming blue again.

I love the military vigour

Paraded on the Field of Mars: ${ }^{8}$

Stout-hearted foot troops and hussars

In orderly and pleasing figure;

Torn battle colours held on high;

Smart ranks in measured rhythm swaying;

Glint of brass helmets, all displaying

Proud bullet scars from wars gone by.

And, martial capital, what pleasure

To hear your fortress cannon' 9 roar

When the Tsaritsa adds more treasure -

A son - to the Imperial store;

Or Russia celebrates once more

Defeat of our opponents' legions;

Or when Nevá's blue ice fragments, And she, saluting Spring, sweeps hence

The shattered ice to ocean regions! 
O fair Petropolis, stand fast, Unshakeable as this great nation:

So that the elements, at last

Subdued, may seek conciliation!

And may the Finnish waves now cast

Aside hate born of long subjection,

And not with futile insurrection

Disturb great Peter's ageless sleep!

There was a dreadful time ... still deep

Its imprint on our generation ...

My friends, that time, remembered well,

Shall be the theme of my narration.

It is a sombre tale I tell.

\section{PART ONE}

November's chilly breath pervaded

The city's streets, as daylight faded.

Dull waves mouthed malice as they ran

To break against ornate defences:

Nevá was tossing, like a man

Confined to bed with fevered senses.

Now it was late, and dark; fierce rains

Beat churlishly on window panes,

While mournfully the wind lamented.

Just at this time a young man came

Back home from seeing friends. His name?

Yevgeny ${ }^{10}$ - let us be contented

To call our hero this: its sound

Is pleasing, and my pen has found

It an agreeable convention.

His surname we don't need to mention:

In ancient times it may have been 
A shining object of devotion ${ }^{11}$

And eulogized by Karamzin ${ }^{12}$

In native annals - but what notion

Do people have of it today?

Our hero earns his honest pay

As clerk, lives somewhere as a boarder,

Shuns those ordained to rule and order,

Gives his dead ancestors no thought

And sets the vanished past at naught.

Yevgeny came home and, undressing

Got into bed. He tossed and turned,

But could not sleep, for in him burned

All those concerns he found most pressing.

What did he think about? That he

Was poor, condemned to drudgery:

For work he must, to make a living

And still maintain his self-respect;

That God had shown great thrift when giving

Him brains and wealth, while that select

Fraternity of men set over

The common folk could live in clover,

Though lazy, not to say inept;

That he had been a clerk for merely

Two years. He also thought that clearly

The weather, turning worse, had kept

The river rising in proportion.

All bridges would, as a precaution,

Have been removed, so he'd not see

Parasha for some days, maybe.

Yevgeny sighed, and conjured visions,

As poets do when they compose:

'Get married? Why not? I suppose 
It's not the lightest of decisions.

But then I'm young; my health is strong;

I'm ready to work hard and long;

We'll find a place that can be rented

And build a simple, homely nest:

Parasha will be well contented.

And after some time, if we're blessed

With children, and I get promotion,

I can entrust to her devotion

Child-rearing and the household tasks ...

And so until we meet our Maker,

When our grandchildren in God's acre

Will bury us - that's all one asks ...'

So ran his thoughts. And deep depression

Assailed him, and he wished the wind

Would not howl with such dull expression,

The rain not rage so as it dinned

Upon the window ...

Sleep invaded

His weary eyes at length. And when

The harsh night's sombre tints had faded,

Day's pallid light returned again ...[3]

That awful day!

Nevá all night

Had pressed towards the sea, engaging

The savage tempest, wildly raging ...

And had to give way to its might ...

By morning crowds had come to wonder;

They thronged to watch the jets of spray,

Huge waves that reared, to crash like thunder:

The mighty elements at bay.

But bottled up by gale winds squalling

In from the Gulf, ${ }^{13}$ Nevá turned back, 
And in retreat, with rage appalling

To see, swamped islands in her track.

The tempest blustered unabated;

Nevá swelled up and roared, frustrated -

A seething, effervescent brew -

Then with a wild beast's frenzy threw

Herself upon the city. All now ${ }^{14}$

Took flight before her; all around

Became deserted; cellars drowned:

Through gratings gushed the turbid water,

Intent on violence and slaughter;

And fair Petropolis must lie

Plunged, Triton-like, in waves waist-high.

Assault! Alarm! Fierce waves are breaking

Like thieves into the houses. Snaking

Adrift, boats buffet, smashing panes.

Those wares from which the merchant gains,

The meagre trappings of privation -

All flotsam from the inundation:

Tin pedlars' trays, debris of huts,

Wrecked bridges, beams, roofs, rafters, struts -

And coffins from the graveyard, sailing

Along the street!

The people fear

God's judgement, for the signs are clear:

No food, no shelter; unavailing

Their cries for help.

In that dread year

Our former sovereign Alexander ${ }^{15}$

Still ruled in glory. Mournfully

He stepped out on the balcony

And spoke: 'The Tsar is no commander

Of God's own elements.' Then rapt 
In sombre thought he sat, surveying

The scene of woe, as waves now lapped

The skirts of broad piazzas playing

The part of lakes, with streets conveying

Fresh torrents to them; while remote,

An island hulk, the Palace drifted.

The Tsar spoke: calling for a boat,

His generals ${ }^{[4]}$ set sail and lifted

The watery blockade; they sped

Along streets annexed by the river,

Defying danger, to deliver

The drowning masses, seized with dread.

With paws upraised in admonition

As they fulfil their guardian mission

Upon a lofty portico

In Peter's Square, ${ }^{16}$ two life-like lions

Stand watch outside a noble scion's

New mansion. ${ }^{17}$ Here Yevgeny, so

Pale-faced, sat motionless. Although

The tempest howled, he sat unhearing

Upon the marble creature, fearing,

Poor fellow, for another. Quite

Unmindful of the water's height -

Though, soaked by waves, his feet were freezing -

Dead to the rain's chastising might,

Unheeding of the wind which, seizing

His hat, had flung it out of sight,

Yevgeny gazed into the distance,

His eyes in desperation fixed

On one point. Meeting no resistance,

Immense waves raging there had mixed

The depths into a deadly potion;

There wreckage in erratic motion 
Was drifting, aimless ... There: yes, there -

O God! - right by the waves, near where

The Gulf begins: a fence, untended;

A lonely willow; the unmended

Clapboarding of a battered hut -

And there: the widow and her daughter,

His love, his dear Parasha ... But

Was this a dream in which he sought her? -

Is all our life, devoid of sense,

A dream: Fate's jest at Man's expense?

And he, transfixed in every feature,

As if chained to the marble creature,

Could not dismount: on every side

Was water, water, far and wide.

And turned away from him, in splendid

Indifference to Nevá's blind force,

Unshakeable, as if suspended

On high, there sat with arm extended

The great bronze idol on its horse. ${ }^{18}$

\section{PART TwO}

With no more heart for devastation, And weary of brutality,

The river turned back to the sea -

Proud of its insubordination,

And after vicious molestation

Abandoning its prey. A mob

Of savage cut-throats smash and rob

Their way through some ill-fated village

With no less vigour: havoc, pillage,

Blind panic, bloodshed, screams, abuse! 
Then, burdened with their loot, the haggard, Dog-weary bandits flee: each blackguard Fears capture and the hangman's noose And scatters booty unlamented.

Streets opened; the unprecedented Flood levels started to reduce. Yevgeny felt his fears augmented By dark conjecture as he sped Towards Nevá in in hope and dread. The waves, though pacified, were haunted By their great victory: undaunted They foamed, as if beneath the spray A low flame kept the waters seething; And so the river fretted, breathing Hard as a steed hot from the fray. Yevgeny looked: a boat was waiting. He called and ran towards it, rating This godsend a sure sign of grace, And for a copper coin ${ }^{19}$ was taken Across the waves. The boat was shaken, Yet carefree was the boatman's face.

Long with the dire waves he contended As oarsman he was unsurpassed And though at times the fight seemed ended As down into a trough descended

Boat and audacious crew, at last They reached the shore.

\section{Yevgeny hastened}

To the familiar neighbourhood

Along familiar streets he could

But scarcely recognize. So, chastened

By fearful sights, he hurried on, 
Poor fellow! Here a house was gone:

Uprooted; here debris lay scattered

About; here still stood, mauled and battered,

Some crippled houses. All around,

As if upon a battleground,

Lay corpses. Feeble from the scourging

Of thoughts too hard for him to bear,

He gasped and in distraction verging

On frenzy ran headlong to where

Fate stood with tidings, uninvited,

As with a letter, stamped and sealed.

Now he was near: the Gulf was sighted,

And soon their house would be revealed ...

But what was this?

He stopped. Retracing

His steps, he turned - continued pacing.

He looked ... walked on ... and looked once more ...

There was the willow. He was sure

Their gate was here. Could it have vanished?

Where was their house - not washed away?

And dark thoughts which would not be banished

Beset him. Like a beast at bay

He circled, muttering; then, taking

Hold of his brow, he started shaking

With sudden laughter.

Night's dark shroud

Enclosed the town; distraught and cowed,

Its citizens could find no slumber

But, seeking remedy in number,

Discussed the day's events.

Dawn's rays

Broke through the weary clouds' dull haze

To shine upon the peaceful city;

They found no trace of yesterday's 
Dire storm: the scene of woe and pity,

Bathed in Aurora's purple sheen,

Had settled back into routine.

The streets were open: people, showing

Cold unconcern, were briskly going

About their business. A parade

Of lowly clerks left home and made

Its way to work; while, naught despairing,

A merchant sorted through his wares

To find the answer to his prayers:

Undamaged stock to sell, so squaring

His losses. Boats were carted off

From courtyards.

Meanwhile Count Khvostov,20

The muses' pet, in deathless verses

Sang of the city's dire reverses

(So smartly had he dashed these off).

But as for my poor, hapless brother ...

His frail mind could withstand no more

Such harsh blows, dealt one on another

By Fate. The wild, tumultuous roar

Of wind and waves reverberated

Inside his head. Withdrawn, unsure,

He roamed, his poor mind lacerated

By nightmare thoughts of death and doom.

Time passed: a week, a month ... His room

Was taken to have been vacated;

And when our hero's lease expired,

His bleak abode was soon acquired

As lodging by a needy poet.

Yevgeny's things remained still there.

As for the world, he ceased to know it,

But wandered all day, sleeping where 
He could upon the quay. Donated

Odd scraps of food made up his fare.

His shabby clothes began to tear

And fall to pieces. He was baited

By spiteful children pelting him

With stones. He often deviated

Onto the roadway, eyes too dim

(So it appeared) to note his blunder:

Although the coachmen whipped him, he

Seemed deafened by the stridency

Of thoughts which raged within like thunder.

So he dragged out the mortal span

Left to him, neither beast nor man,

Not this nor that, without a station

In this world or the next ...

One night,

As summer reached its termination,

He slept on the embankment. Quite

A wind was gusting. Flecked with white,

Waves lapped the granite steps: expended,

And breathing oaths, as one offended

Who begs a judge to intercede:

In vain - his Lordship pays no heed.

Yevgeny woke to winds lamenting;

Rain dripping; darkness unrelenting;

A watchman's cries, far off somewhere,

Dissolving in the damp night air ...

Yevgeny started up, the stirring

Of memories like old wounds spurring

Him on. He set off hastily

And roamed the streets. Then, suddenly,

He stopped and, full of apprehension,

Looked all around. He stood below

Some columns, stately in dimension. 
Two lions on a portico

Stood, paws upraised in admonition

As they fulfilled their guardian mission;

And nearby - awesome sight indeed -

A granite bluff: as if suspended

On high, there sat with arm extended

The great bronze idol on its steed.

Yevgeny shuddered. He was troubled

By painful clarity of thought. ${ }^{21}$

He knew this place, where once in sport

The flood had played and waves had bubbled,

Defiant in their fierce despair;

He knew these lions, and this square,

And him whose bronze head dominated

The darkness from its lofty height -

Whose fateful will had on this site

Decreed a city be created.

His figure awesome to behold!

Upon that brow what thought untold!

What armoured might, aloofly ample!

And in that steed what fire, what force!

Where are you galloping, proud horse,

And where will those hooves plunge and trample?

Fate's mighty master! Was not this

How you, with curb of iron halting

Her flight, reined Russia back from vaulting

Into the bottomless abyss?[5]

Yevgeny paced in agitation

Around the statue's massive base

And wildly gazed upon the face

Of him who straddled half creation.

His chest was tight. His brow was chilled, 
Pressed to the railings. Darkness filled

His eyes. The prey of passions blazing

Within him, he stood sullenly

Before the royal effigy;

And quivering with fury, raising

His fist, as if compelled by some

Dark force to blind, impulsive action,

He hissed through teeth clenched in distraction:

'You ... builder of grand schemes! I'll come

And get you!' - and then ran off, numb

With terror from a sudden vision:

He thought the fearsome tsar had turned

By slow degrees his face, which burned

With righteous anger and derision ...

And through that dark, deserted square

Yevgeny ran, and was aware

Of cumbrous hooves behind him pounding

The roadway, crashing and resounding

Like thunder in the still night air;

For after him, with arm extended,

The Bronze Colossus on its steed

Charged at the gallop and offended

The moonlit calm with its stampede.

And then, no matter where he wended

His way, he found that all night through -

Poor, hapless wretch - he was attended

By bronze hooves beating their tattoo.

And after this ordeal, whenever

Chance brought him once more to that square,

He'd clasp his heart in an endeavour

To calm its anguish. With an air

Of panic-stricken guilt and terror, As if avowing flagrant error, 
He'd snatch his frayed cap from his head And with averted eyes would thread His way around the edge.

Some distance

Offshore a little island can

Be seen. ${ }^{22}$ Sometimes a fisherman, Kept out late by his own persistence, May land there with his nets to cook His poor meal; or some clerk might look Around on Sunday while out boating.

In that forlorn place not a blade

Of grass grows. Here had drifted, floating Unhindered as the floods had played, A battered hut. It stayed there, stranded: Like a black bush. A barge moored there Last year in spring, and workmen landed To cart the hut off. It was bare And almost wrecked. Outside, unwitting, They stumbled on Yevgeny near The threshold. His remains were here Interred with simple rites, as fitting. 


\section{NOTES BY A.S. PUSHKIN TO THE POEM}

[1] Algarotti says somewhere: 'St Petersburg is the window through which Russia looks on to Europe.'23

[2] See Prince Vyazemsky's verses to Countess $Z^{* * *} .24$

[3] Mickiewicz has described the day preceding the St Petersburg flood in some fine verses in one of his best poems, 'Olieszkiewicz'. It is just a shame that his description is not accurate. There was no snow; the Neva was not frozen over. Our description is more accurate, although lacking the bright colours of the Polish poet. 25

[4] Count Miloradovich and Adjutant-General Benckendorff. ${ }^{26}$

[5] See the description of the monument in Mickiewicz. It is taken from Ruban, as noted by Mickiewicz himself. ${ }^{27}$

\section{TRANSLATOR'S NOTES}

1. Vasily Nikolayevich Berkh (1781-1834), geographer and historian. His work $A$ Detailed Historical Account of All the Floods That Have Occurred in St Petersburg, published in 1826, contains the description of the 1824 flood to which Pushkin refers.

2. Tsar Peter I, known as Peter the Great (born 1672, reigned 1682-1725, jointly with his half-brother before 1696). Although named in earlier drafts of the poem, he remains anonymous throughout the work in its final version. Nevertheless his identity is quite clear. The Neva delta, sparsely inhabited by Finns, was captured from the Swedes in the spring of 1703, during the Great Northern War (1700-25). Peter immediately decided to build a new city there, starting with the Fortress of St Peter and St Paul on an island in the Neva. The construction of the showpiece city in the inhospitable marshes cost thousands of human lives, not to mention the huge burden on the Exchequer.

3. In 1712 Peter decreed that the capital be transferred from Moscow to his new city. St Petersburg remained the seat of government for just over 200 years. In 1918, fearing that the 'cradle of the Revolution' was strategically vulnerable to antiBolshevik forces, Lenin decided to restore Moscow to its ancient status as capital. 
4. Literally 'Peter's creation' in the original. The official name of the city was St Petersburg (Sankt-Peterburg, often shortened to Peterburg or, colloquially, Piter). At the outbreak of World War I this was considered too Germanic and for patriotic reasons changed to Petrograd. After Lenin's death in 1924 the city was renamed Leningrad in his honour. In 1991 it became St Petersburg again. In the poem Pushkin uses the Slavonic form Petrograd (used before him by the poet Batyushkov), as well as the mock-Greek 'Petropolis'. The name St Petersburg itself appears only in the subtitle 'A St Petersburg Story'.

5. The river Neva is wide and full-flowing, although only 46 miles in length from Lake Ladoga to the Gulf of Finland. The name, deriving from Finnish neva ('bog') is stressed on the second syllable in Russian.

6. A reference to the 'white nights' of midsummer when at the latitude of St Petersburg the sun never dips far enough below the horizon for twilight to give way to darkness.

7. The Admiralty, a neoclassical building erected soon after the Napoleonic Wars to the design of the architect Zakharov, has a prominent gilded spire. This has become, like the equestrian statue of Peter, an emblem of the city.

8. A large square (Marsovo polye in Russian) where military parades were held.

9. Cannon salutes were fired from the Fortress of St Peter and St Paul on important occasions such as those listed by Pushkin. The annual breaking up of the river ice was - and is - an eagerly awaited occurrence, heralding in dramatic fashion the end of winter.

10. Pushkin in playful mood picks a name familiar to his readers from his novel in verse Yevgeny Onegin, published in 1833. This arbitrary bestowal of a first name and the dismissive withholding of Yevgeny's surname four lines later serve to emphasise the hero's anonymity. Pushkin thus creates a parallel between Yevgeny and Peter (see note 2), a technique repeatedly used in the poem to highlight differences rather than similarities between the two protagonists. 
11. The reference to Yevgeny's illustrious forebears suggests that, like Pushkin, he was descended from the old boyar aristocracy whose power was largely broken by Peter the Great.

12. Nikolay Karamzin (1766-1828), historian, author of the ground-breaking twelvevolume History of the Russian State. He was also important as a literary figure, writing stories which popularised the sentimentalist movement in Russia and exemplified his belief that the Russian literary language should draw more closely on popular speech. Pushkin was closely acquainted with Karamzin from childhood on, when the latter was a frequent visitor to his parents' house in Moscow. In 1820, when Pushkin was in trouble for writing and circulating subversive poems, Karamzin pleaded with the Tsar on his behalf. Although Pushkin was subsequently exiled to the Caucusus, Karamzin's intervention may have averted a harsher punishment.

13. The Gulf of Finland.

14. In the original this line does not rhyme with any other, a unique divergence from the tightly ordered rhyme scheme which was presumably deliberate on Pushkin's part. The effect is analogous to that of a dissonant chord in music, emphasising the chaotic and unpredictable nature of the river's sudden incursion into the city. This feature has been preserved in the translation.

15. The Emperor Alexander I (born 1777, reigned 1801-25). Pushkin subversively emphasises Alexander's weakness and helplessness, compared with his forebear Peter the Great.

16. The square on which the Bronze Horseman stands, also formerly known as Senate Square. In 1925 it was renamed Decembrists' Square in memory of the unsuccessful Decembrist revolt which took place there on 14 December 1825 (Old Style) following the death of Alexander I. In 2008 the original designation Senate Square was formally reintroduced. 
17. Pushkin is describing an actual house, that of Prince Lobanov-Rostovsky. It formerly stood at the corner of Admiralty Boulevard. There is a contemporary account of a man taking refuge on one of the lions during the 1824 flood, just as Yevgeny does in the poem. It was outside this house that Nicholas I stood when he ordered shots to be fired at the rebel troops in Senate Square during the Decembrist revolt.

18. The famous equestrian statue of Peter the Great was commissioned by Catherine the Great and unveiled in $\mathbf{1 7 8 2}$ to mark the centenary of Peter's accession to the throne. The monument, designed by the French sculptor Étienne Maurice Falconet (1716-91), shows Peter mounted on a horse rearing in the act of trampling on a serpent. The statue stands on an enormous granite monolith found some eight miles outside the city which had to be dragged overland and then shipped by special craft. Falconet described the concept of his monument as follows: 'My tsar does not hold a sceptre; he raises his beneficent hand over the country across which he is riding; he climbs this crag which serves as his foundation and is an emblem of the difficulties he has surmounted.' Others have seen the statue in a more ominous light. The Polish poet Mickiewicz for instance, with whom Pushkin was personally acquainted, described Peter's image as 'a laurel-wreathed wielder of the knout in a Roman toga'. Pushkin's own ambivalent attitude towards Peter is evident throughout the poem.

19. In the original, a grivennik, a colloquial term for a ten-kopeck coin. The critic Anthony Briggs has suggested that this is a deliberate echo of the obolus, a coin of nominal value paid according to Greek myth to Charon to ferry the souls of the dead across the Styx (A.D.P. Briggs, Alexander Pushkin: A Critical Study, London and Canberra, 1983, p. 131). The strange unreality of the episode certainly lends weight to this interpretation: the boat, described as a 'godsend' ('nakhodka'), appears as if by prearrangement, while the ferryman, untroubled by the still stormy waters, is apparently prepared to put his life at risk in return for the paltry sum of ten kopecks.

20. Dmitry Ivanovich Khvostov (1757-1835) was a senator and writer of third-rate verse, the butt of much ridicule from other contemporary poets. 
21. With this phrase Pushkin makes it clear that Yevgeny's 'rebellion' is not the deluded act of a madman. His mind clears momentarily, enabling him to see Peter, who built the city on marshland liable to flooding, as the original cause of his misery.

22. Anna Akhmatova identified this as the island of Goloday, based on a comparison of this passage with a description of Goloday in one of Pushkin's stories. Goloday is situated to the north of Vasilyevsky Island, separated from it by a narrow river. What is significant about this is that the five leading Decembrists who were hanged for their part in the uprising were said to have been buried on Goloday, in unmarked graves. If Akhmatova is right, Yevgeny's burial on the island must represent a further cryptic link between him and the Decembrists.

23. Francesco Algarotti (1712-64), Venetian Enlightenment philosopher and polymath. He travelled widely, including some time spent in St Petersburg. The phrase quoted is from his Letters on Russia of 1739.

24. The poet Pyotr Andreyevich Vyazemsky (1792-1878) was a close friend of Pushkin. The poem in question is his 'Conversation of 7 April 1832', dedicated to Countess Yelena Zavadovskaya, to whom Pushkin also wrote poetry.

25. Adam Mickiewicz (1798-1855) is generally regarded as Poland's greatest poet. Exiled to central Russia in 1824 for political agitation against tsarist rule, he met Pushkin two years later in Moscow and they became firm friends, meeting both there and in St Petersburg. In 1829, partly through the efforts of Pushkin and his circle, he was permitted to leave the Russian Empire and spent the rest of his life in Western Europe, mainly in Paris. Pushkin's support for Tsar Nicholas I's actions in subduing the Polish insurrection of $1830-31$ led to a personal rift between the two poets, although they continued to admire each other's work. Like Pushkin, Mickiewicz was not in St Petersburg to witness the flood of 1824 (he arrived there a couple of days later), but in his poem 'Oleszkiewicz' (of which Pushkin had a copy) later described the day preceding it. Pushkin's note may be an attempt to cast doubt on the accuracy of Mickiewicz's view of Russia in general. 
26. Mikhail Andreyevich Miloradovich (1771-1825), Russian general of Serbian origin; from 1818 Governor General of St Petersburg; assassinated by rebels during the Decembrist revolt. Alexander von Benckendorff (1781-1844), Russian general of Baltic-German origin, from 1826 head of the Third Section (secret police) created by Nicholas I with Benckendorff's support following the Decembrist revolt.

27. Mickiewicz's poem 'The Monument of Peter the Great' ('Pomnik Piotra Wielkiego') presents a much more negative view of Peter, compared with Pushkin's eulogy at this point. Both here and in his note 3 Pushkin seems intent on emphasising his own patriotism and loyalty to Nicholas's regime by contrasting it with the dissident and anti-Russian standpoint taken by Mickiewicz. His motives in this are not clear: perhaps it was part of his ongoing literary feud with the Polish poet, perhaps an attempt to divert the attention of the censor (in his case, Tsar Nicholas, who had insisted on personally vetting all Pushkin's works himself) from the politically more ambivalent aspects of his own poem (or both of these). Confusingly, he goes on to claim that Mickiewicz's description of the Bronze Horseman 'is taken from Ruban, as noted by Mickiewicz himself'. In fact all Mickiewicz says, in a footnote to a line of his poem describing the transportation of the statue's granite pedestal to St Petersburg, is that the line in question was translated from a Russian poet whose name he had forgotten. Pushkin himself supplies the name of Vasily Grigorevich Ruban (1742-92), author of the eulogistic poem 'Inscriptions to the Thunder Stone' ('Nadpisi k Kamnyu Gromu'). His claim that Mickiewicz's description of the statue is based on this is clearly misleading, as he would have been well aware that Ruban's poem commemorates only the transportation of the immense stone pedestal before the statue itself was erected. This adds a further layer of obfuscation to what is already a confusing picture. We can only assume that Pushkin's references to Mickiewicz in his notes were part of a now obscure game of cat and mouse carried on with his royal censor. (See Michael Basker, 'Notes of Confusion: On the Footnotes to The Bronze Horseman', Two Hundred Years of Pushkin. Vol. 2: Pushkin: Myth and Monument (ed. Robert Reid and Joe Andrew), Amsterdam and New York, 2003, pp. 139-157.) 


\section{TRANSLATOR'S COMMENTARY}

In the late summer of 1833 Alexander Pushkin left St Petersburg and headed east towards the Urals on the first stage of a journey to the main centres of the Pugachov revolt of the 1770s. Pushkin had become involved in research into the lives and careers of two men in particular. One was Yemelyan Pugachov, the peasant rebel and pretender to Catherine's throne; the other was Peter I, the dynamic tsar who had founded St Petersburg in 1703. He was supported in his studies by Nicholas I, who granted him access to the government archives (hoping no doubt to compromise Pushkin's reputation as a bard of freedom by installing him as semi-official court poet and historian).

As Pushkin left the capital to research the Pugachov revolt in the field, a violent storm broke: trees were blown down, the swollen river Neva burst its banks, and the marshes around the city were lashed into white waves. Writing to his wife on 20 August, Pushkin asked: 'Is it possible that you have had a new flood? And what if I have missed this one too? It would be a shame.' He was referring to the disastrous flood of 1824, which had caused much loss of life and damage in St Petersburg. Pushkin had not witnessed the flood himself, as he had been exiled to his family's country estate at Mikhaylovskoye, but he had subsequently read first-hand accounts of it and had even considered making it the subject of a poem.

After completing his historical researches in the autumn of 1833, Pushkin spent six weeks at Boldino, his country estate in Nizhny Novgorod province. Here he wrote the story The Queen of Spades and finished his History of Pugachov (published the following year with the title altered at the Tsar's behest to The History of the Pugachov Mutiny). Here too, on 6 October, he began The Bronze Horseman, a narrative poem about the 1824 flood which was completed in just over three weeks.

Nicholas I, who had appointed himself as Pushkin's personal censor, demanded substantial changes to the text of The Bronze Horseman. Pushkin could not agree to these, and as a result only an extract from the poem was printed during his lifetime. Soon after his death in 1837 the poem was published in full in his journal Sovremennik (The Contemporary), but in a sadly mutilated version: in order to get it past the censor, Pushkin's no doubt well-meaning friend, the poet Zhukovsky, had 
made wholesale alterations. Pushkin's original text was in fact not published in full until 1904, since when The Bronze Horseman has been generally acclaimed as one of his most inspired poetic creations.

Apart from eyewitness accounts of the 1824 flood which Pushkin had read, a variety of other sources influenced the writing of The Bronze Horseman. There were for instance his studies of the Pugachov revolt and of Peter the Great, both of which are reflected in the imagery of the poem. Another catalyst was a series of poems on the subject of Russia written by his Polish contemporary and friend Adam Mickiewicz, a clandestine manuscript copy of which Pushkin obtained in July 1833. In these Mickiewicz portrays Peter the Great as a tyrant, and his creation St Petersburg is called 'the northern Babylon'. One poem recalls how one day Mickiewicz and Pushkin walked together near the famous equestrian statue of Peter by the sculptor Falconet, commissioned by Catherine the Great as a tribute to her predecessor; here Peter's image is described as 'a laurel-wreathed wielder of the knout in a Roman toga'. Although Pushkin himself once conceded that Peter's decrees had been 'written with the knout', he did on the whole admire Peter's radical programme of reforms, hailing him on one occasion as a 'revolutionary by the grace of God'. There can be little doubt that one of Pushkin's intentions in writing The Bronze Horseman was to answer, or at least offer a more balanced view in response to, Mickiewicz's attacks on Peter and St Petersburg. This is particularly apparent in the Introduction to the poem.

In the Introduction Peter appears as a man, yet already statuesque in appearance, as he stands gazing over the Neva estuary in territory just conquered from the Swedes. He envisions the building of a great new city a 'window to the West' of major strategic, economic and cultural significance. With only the words 'A hundred years have passed' as link, the scene shifts to St Petersburg in Pushkin's day, a dramatic effect appearing to show the city rise fully formed from the marshes at Peter's command. Pushkin then makes an unambiguous declaration of his feelings for the capital ('O how I love you, Peter's daughter!'), elaborating on this with a delightful kaleidoscope of his own heartfelt enthusiasms, in several instances pointedly rebutting specific slurs made by Mickiewicz. At line 84 there is a change of 
tone as personal delight gives way to the kind of impersonal grandiloquence more appropriate to a public ode composed for some grand occasion: 'O fair Petropolis, stand fast,/ Unshakeable as this great nation...' However, the lofty sentiments expressed in these lines have a certain hollow ring, in particular the hope that the Finnish waves will not disturb 'great Peter's ageless sleep' with 'futile insurrection': as Anthony Briggs has pointed out, ${ }^{1}$ this is undermined by the following section referring directly to the 1824 flood, when the destructive power of the waves could hardly be dismissed as 'futile'. In this final section of the Introduction we are aware of yet another change of voice: from the declamatory style of the preceding lines Pushkin suddenly drops into the quiet, candid tones of someone addressing an intimate circle ('my friends') on matters of serious concern.

The main body of the poem, which is in two parts, tells the story of Yevgeny, a poor clerk in government service, whose fiancée Parasha is drowned in the flood of 1824. Driven out of his mind with grief, Yevgeny becomes a homeless vagrant and for nearly a year roams the streets, subsisting on charity. One day he encounters the equestrian statue of Peter the Great in Senate Square and in a moment of clarity sees Peter as the person ultimately responsible for Parasha's death. It was after all he who had built the city in such inhospitable surroundings, without regard for the lot of ordinary folk who would have to live and work there. Yevgeny shakes his fist at the statue and utters an incoherent threat, but immediately flees in terror as he imagines that Peter is pursuing him on horseback. A few months later Yevgeny's corpse is found on a little island in the Neva, next to the remains of Parasha's wooden house: both he and the house had been washed up there together. Yevgeny is given a pauper's burial on the island.

Behind this uncomplicated story lies a seemingly inexhaustible wealth of references and parallels, metaphors and polarities. On a quite separate plane from Yevgeny's personal tragedy, we are aware throughout the poem of an almost mythological struggle taking place between the warring principles of order and chaos. Into this overall struggle are absorbed other, more specific conflicts and polarities such as man versus nature, the autocracy versus the people, reason versus instinct. In the very act of conceiving and creating his city in the northern swamps, Peter has imposed order on the primeval natural scene depicted at the beginning of the poem. The city itself, 'graceful yet austere' in its classical design, is, as much as the Falconet statue, Peter's living monument, carrying on his struggle against the 
'wild, tumultuous' Finnish waves. Its granite banks may hold the unruly elements in check for most of the time, but even they are helpless against such a furious rebellion as the flood of 1824. The waves' victory is, admittedly, short-lived: the flood soon recedes and the city returns to normal. Even so it is clear that they can never be decisively defeated; they live to fight another day.

The Falconet statue itself may be seen in terms of polarity and conflict, as an image of nature (the horse) subjugated to the will of man (Peter). However, in the poem it is not quite as straightforward as that, for the horse also represents Russia, 'reigned back' by Peter 'with curb of iron' just in time to save it from the disaster of 'vaulting/ Into the bottomless abyss'. Pushkin emphasises the horse's liveliness and vigour ('And in that steed what fire, what force!'), implying that the vital but undirected energies of the Russian people require the disciplined dressage skills of a strong ruler to ensure they are bent to profitable use. It is also clear that such effective rule, desirable though it may be, will inevitably be achieved at the expense of individual suffering. The horse is indeed completely under Peter's masterly control, yet is still capable of causing destruction, injury or death:

\footnotetext{
Where are you galloping, proud horse, And where will those hooves plunge and trample?
}

Later in the poem it is Yevgeny, the hapless individual citizen, who hears those hooves beating the ground behind him as he flees in terror for his life, pursued by rider and horse, by ruler and ruled: in other words, by the combined weight of state power.

The image of horse and rider as a symbol of the people and their masters clearly fascinated Pushkin. He uses it in his play Boris Godunov to suggest in the same way that without firm leadership the people will revert to anarchy and violent rebellion. In the words of Basmanov, the commander of Boris's army:

The people always have a latent tendency towards disorder:

So a mettlesome horse chafes at the bit ...

But what of it? The rider calmly controls his horse ...

To which the rather less sanguine Tsar replies: 
Among Pushkin's manuscripts there is a sketch of Falconet's monument, immediately recognisable as such from its granite plinth, the rearing horse and the serpent trampled by its hooves. Only one thing is missing: there is no rider. A riderless horse even appears in The Bronze Horseman itself. It is introduced as an image for the river when the Neva, still agitated after the flood, is said to be panting 'Hard as a steed hot from the fray'. The implication in the original Russian is that the horse has lost its rider, for it is described as 's bitvy pribezhabshiy kon', literally 'a horse which has bolted from the battlefield'. In this simile Pushkin subtly links the image of the river with that of the horse in Falconet's statue.

Like the horse, the river represents not only nature and instinct, but also the potentially destructive power of the people. Throughout the poem the techniques of personification and animation are called upon to make the river appear as a living creature: it tosses restlessly in its confines like a sick man in his bed; it attacks the city with all the frenzy of a wild beast; waves enter basement windows like burglars. And in the most extended (and most revealing) simile, the river retreating after the flood is likened to a horde of bandits who have attacked a village, killing, destroying and plundering, and then flee, fearing retribution by the authorities. In their haste the bandits scatter their booty - a visually precise image for the flotsam left behind by the receding waters. There can be no doubt that this simile, like many others in the poem, was suggested to Pushkin by his study of the Pugachov revolt. He had been struck by the ease with which the state's authority crumbled in those areas affected by the revolt, and by the wanton and gratuitous violence of the uprising itself. These aspects can also be found in the simile of the bandits. Nothing can stop their whirlwind-like passage through the village, brilliantly evoked in Pushkin's original by a pell-mell bombardment of verbs and nouns which make their mark with the force of punches or the repeated stabs of a knife:

... lómit, rézhet,

Krushít i grábit: vópli, skrézhet,

Nasíl'ye, brán', trevóga, vóy!

This is no planned uprising; nobody would attempt to justify such bloodletting as the purposeful surgery of a revolution led from the front. The violence is an end in itself, 
its sole raison d'être the release of blind passions. Even the booty, which might be regarded as the motive for it all, is in the event abandoned without thought as the destructive instinct gives way to another, equally strong: that of self-preservation.

So the wild fury and obliterating power of the flood waters are equated with the violent and spontaneous disorder unleashed as the people's resentment against authority boils over. The resentment - the perception of injustice - is always there. Nearly a year after the flood, the waves beat against the granite embankments like a petitioner ('chelobitchik') at the doors of a judge or magistrate, begging him to intercede in some instance of injustice. The judge, we are told, ignores the petition. In other words, the people have now lost the initiative and must once more submit to higher authority.

That higher authority is represented most clearly by Peter. What is more, he represents it in a way which sets him apart from the mass of humanity and even (so Pushkin hints, as we shall see) from such run-of-the-mill autocrats as Alexander I. Only in the first twenty lines of the poem does Peter appear as a living person. The action then shifts forward abruptly by a hundred years, and the rest of the poem is set in a time when Peter is obviously long since dead. Yet despite this we have a sense throughout of Peter's living presence, as if he had managed to avoid death in a quite unmortal way. The section evoking contemporary St Petersburg - Peter's youthful creation, in which his spirit lives on - insinuates the first slight suggestion of this. Then comes a more explicit hint, as Pushkin voices the hope that the Finnish waves will not 'disturb great Peter's ageless sleep'. Peter, we must conclude, is not dead after all: he will awake from his sleep if danger should at any time threaten his capital city, the heart of the nation. In common with other historical figures (Drake, Barbarossa, King Arthur), Peter seems here to have acquired the legendary reputation of being the immortal guardian of his nation's welfare. By contrast, the Emperor Alexander's weak disclaimer that 'The Tsar is no commander/ Of elemental forces' shows him to be as mortal as the next man, while reminding us that Peter, the 'mighty lord of destiny', was indeed able to command the elements.

Peter's role as guardian of Russia's destiny is realised in visual terms by his statue, which looks out over the city from its lofty vantage and actively defends the interests of the state by pursuing Yevgeny. It is of course deeply ironic that Peter should apparently perceive this lone and impotent protester as a prime threat to public order: that it is Yevgeny's muttered threat, and not the hostile waves, which 
finally rouse the autocrat from his 'ageless sleep'. Ironic, too, that Pushkin never refers to the statue as such, but calls it an 'idol' ('kumir') or 'effigy' ('istukan'). This predictably offended Nicholas I, his regal censor, since in Russian usage, as in English, an idol is undeniably the image of a false deity. Even so it is significant that Pushkin should in this way accord Peter the status of a god or demi-god, albeit one who is in some way flawed. Could the flaw lie in Peter's hubris, his usurping of divine functions in making himself a 'lord of destiny'? This is never spelled out, and any moral judgement of Peter implied by the word 'idol' remains a somewhat ambiguous one: hardly surprising, perhaps, when we recall that Pushkin's admiration for Peter's reforms on the one hand was tempered by distaste for his cruel and tyrannical nature on the other. The mixed fortunes experienced by Pushkin's forebears under Peter the Great may have contributed to his own mixed feelings towards this 'revolutionary by the grace of God'. The Pushkins themselves had belonged to the ancient boyar aristocracy whose power was broken by Peter. On his mother's side, by contrast, Pushkin was descended from Abram Gannibal, one of the new service nobles promoted by Peter to replace the boyars: a black African slave received by Peter as a gift from the Turkish court, Gannibal rose in his service to become a general and landowner.

There are further indications in The Bronze Horseman of Pushkin's equivocal attitude towards Peter. In the Introduction it is less apparent, as here he is concerned to defend Peter against Mickiewicz's strictures, but elsewhere the panegyrics are balanced by darker notes: '... him whose bronze head dominated/ The darkness from its lofty height'; 'His figure awesome to behold!'; 'the fearsome tsar'. The critic Belinsky saw the poem as 'the apotheosis of Peter'. While Pushkin does indeed endow Peter with divine or semi-divine attributes, we may seriously doubt that this is intended as an accolade, or - as implied by Belinsky's comment - that it is the main point of the poem. Pushkin is concerned throughout to emphasise Peter's remoteness from ordinary human life; the 'apotheosis' is but one of the techniques used to achieve this and does not in itself imply approval. Peter appears not as an ordinary human being but as an elemental force: he is an agent in the historical process, and even beyond this he participates in a wider cosmic struggle between order and disorder. We might in consequence be tempted to consider it just as futile to apply moral criteria to this Peter as it would be to judge the waves and flood water. Does he not, like some forerunner of the Nietzschean superman, stand beyond good and evil? 
Pushkin never goes that far. His view of Peter implies if anything a subtle critique of the superman concept (a critique later developed more comprehensively and with greater force by Dostoyevsky in his novels).

But what of Yevgeny? How exactly does he fit into this grandiose cosmic scheme? Before attempting to answer this, we may find it helpful to consider certain striking features of Yevgeny's characterisation. There are for instance the deliberate parallels drawn between him and Peter, no doubt with the dual aim of contrasting the two and at the same time establishing a parity of esteem between them. One example of this is the way Yevgeny's thoughts on the evening before the flood ('What did he think about?') contrast in their purely private and personal ambitions with the public and impersonal aspiration of Peter's thoughts at the opening of the poem ('And he thought...') A further example is the depiction of Yevgeny seated on the statue of a lion in Senate Square at the time of the flood, 'motionless', 'as if chained to the marble creature', in a kind of visual parody of Peter's statue in the same square. Noteworthy too are the (necessarily) cryptic references linking Yevgeny with the Decembrists, whose fate after the failure of their revolt in December 1825 left Pushkin deeply shocked (many of them were, as he himself declared, his 'friends, brothers, comrades'). From internal evidence it is clear that Yevgeny's own revolt against the autocracy (his threatening of the statue) takes place nearly a year after the flood; this dates it to the autumn of 1825, in other words within a few weeks of the Decembrist revolt itself. Anna Akhmatova found another link between Yevgeny and the Decembrists in the identification of the little island where Yevgeny is buried (see above, note 22, for a full discussion of this).

By introducing these features Pushkin would appear to defend the dignity and value of the individual: Yevgeny is accorded equal status with Peter in purely human terms, and his rebellion against state power is shown to be as admirable and significant in its way as that of the Decembrists. Yet turning now to the question of Yevgeny's role in the wider scheme of things, we have to admit that he seems an insignificant third factor in the equation when viewed against the backdrop of the titanic struggle taking place between Peter and the elements. Yevgeny is utterly and completely helpless against both. The flood sweeps away all his dreams of happiness, and it is in the river that he meets his death. Peter's statue, which at their first 'encounter' during the flood had its back turned to Yevgeny as if ignoring him, later hounds him mercilessly when he dares to protest at Peter's role in his suffering. The 
vast, impersonal forces of order and chaos, locked in an unending struggle - these, Pushkin seems to be saying, are the reality: these are the millstones of destiny or of the historical process to which Yevgeny and his kind are but so much grist. This is in itself a bleak enough picture, but it is not all. Far from merely ignoring mankind, fate seems to take a perverse delight in teasing and tormenting in particular such decent, altruistic individuals as Yevgeny. At the end of the poem Yevgeny does at last return to Parasha's house, but he is dead, and the house is a deserted wreck. By a terrible irony of fate his body and Parasha's house have been washed up together, and he lies 'near the threshold' both literally and metaphorically. There is also cruel irony in his lonely burial in an unmarked grave, contrasting starkly with his earlier dreams for the future, when he had envisaged himself and Parasha being buried by their grandchildren and lying together after a long and happy life. Small wonder that Pushkin asks:

\footnotetext{
Is all our life, devoid of sense,

A dream: Fate's jest at Man's expense?
}

And yet despite all this it is abundantly clear that Yevgeny - apparently so peripheral in the overall scheme of the poem - in fact occupies the central place in Pushkin's sympathies. He is 'my poor, hapless brother', 'poor fellow', 'poor, hapless wretch'. Nowhere is there the slightest hint of caricature in Pushkin's portrayal of Yevgeny: never (and it would have been so easy) does he mock his hero's downright ordinariness, or his descent into madness and his potentially grotesque threatening of the statue. As a consequence the overall tenor of the poem is a positive, strongly humanitarian one: balancing and redeeming the tragedy we are aware throughout of Pushkin's deep concern and fellow-feeling for the common man, cast here, as so often, in the role of victim.

\section{III}

One could summarise all this by saying that Yevgeny's theme, like that of Peter, is presented in both major and minor keys. The analogy might be considered appropriate, given that the musical qualities of Pushkin's verse have frequently been commented on by critics. One of the earliest was the poet Delvig, who returned some 
poems Pushkin had sent him with the simple statement: 'This is not poetry: this is music'. What the critics usually have in mind is Pushkin's tone-painting, his use of sound to expressive or descriptive effect (something of which at least, one dares to hope, may even come across in translation). In the case of The Bronze Horseman, however, it can be argued that the poem is musical in other senses too.

Just as The Brothers Karamazov or The Idiot are novels of ideas, The Bronze Horseman is a poem of ideas. Like Dostoyevsky, Pushkin does not develop one central argument but organises his work on the principle of antithesis and polarity. Thus the sadness and pessimism of the closing sections are balanced by the sparkling optimism and joie de vivre of Pushkin's invocation in the Introduction of the city he knew and loved. Similarly, St Petersburg is presented, particularly in the Introduction, as a triumphant symbol of man's conquest of nature, while the elements themselves, rebelling against human domination, are compared to such undesirables as bandits, burglars and frenzied beasts. On the other hand the people of St Petersburg see the flood as 'God's judgement', so justifying it by implication. Sympathy for the justice of the waves' cause is also revealed when they are likened to a petitioner at the door of an unheeding judge. Perhaps the waves too have rights; perhaps man should try to work with nature rather than against her? Such examples are by no means isolated: again and again a point is made, only to be contradicted or put in doubt elsewhere in the poem. This playing of opposing ideas and themes against each other could be thought of as musical in its effect. Indeed, The Bronze Horseman can be shown to possess a remarkably musical structure, in which as in a sonata or fugue each theme is allocated its place in a strictly architectonic scheme.

The poem is divided by Pushkin into three sections (the Introduction, Part One, Part Two), which may be seen as corresponding to the three or four movements of sonata form as established at the time. The last seventeen or so lines of the poem have sometimes been identified as an untitled epilogue, which would make this final section equivalent to a brief fourth movement or finale. The first movement of a sonata, symphony or concerto has a prescribed structure consisting of four sections, and it is interesting to see how closely the Introduction of The Bronze Horseman conforms to this first-movement form.

1. Exposition. Two musical themes are introduced, one in the tonic, the other in the dominant. This corresponds to lines 1-20 of the poem, in which the 
themes of nature and Peter are introduced. As Briggs has pointed out, ${ }^{2}$ in the first eleven lines, which depict primeval nature, the rhyme scheme is based on five-line groups; there is then a switch to quatrains as soon as Peter's plans for the future are mentioned (from line 11). In this way the contrast between nature and man is given formal expression, corresponding in approximate musical terms perhaps to the different keys of the two themes.

2. Development of the themes. This is the section describing St Petersburg in Pushkin's day, lines 21-83. The theme of Peter and his grandiose plans from the exposition is here developed to show his creation, the fruition of those plans, as it exists in the present (lines 21-42), followed by Pushkin's own personal reaction to the city (lines 43-83). The theme of nature, although muted, does recur at intervals. There are references back to the swamps and forests and the Finnish tribes who lived there, while the image of the river itself is subjected to development: now it is confined between granite banks - tamed by man - in contrast to its wildness and freedom in the exposition section.

3. Recapitulation. The musical themes are restated as they appeared in the exposition, but this time both are in the tonic, so that the conflict between them is resolved. In the poem this resolution or reconciliation takes place in lines 84-91, a brief section set apart from the rest by its particularly elevated and rhetorical style. The whole burden of this passage is indeed reconciliation between nature and Peter, as Pushkin appeals to the waves not to rebel against their subjection to the will of Peter.

4. Coda. The short closing section (lines 92-96) is marked by a complete change of tone, as the grandiloquent style of the preceding passage is abruptly replaced by a conversational intimacy and frankness, while pious hope gives way to bleak realism. This passage rounds off the Introduction but also, with its reference to 'the theme of my narration' and its sombre tone, points forward to the events and overall mood of Parts One and Two.

The rest of the poem does not closely follow any of the generally recognised schemes for second and third movements, but there is for these movements in any 
case a wider latitude than for the first movement, which traditionally follows the structure outlined above. Part One, for instance, observes the thematic pattern ABACBC (A = nature/the elements; $\mathrm{B}=$ Yevgeny; $\mathrm{C}=$ Tsar Peter/Alexander), which might be considered an individual variation on the extended rondo form (ABACABA). What is important is that in Parts One and Two Pushkin continues to introduce and develop themes in what can still be seen as a musical way, using the greater freedom allowed in second and third movements.

A further analogy with musical form may be seen in the more or less exact repetition of phrasings and images at different points in the poem, used as a structural feature in much the same way as the leitmotif in music. Obvious examples are the statues of lions (lines 220-225 and 397-399) and the Bronze Horseman statue itself (lines 255-259 and 400-403). A less conspicuous but nevertheless persuasive use of verbal repetition, as noted by Briggs, 3 links the final section of the poem (lines 464-481) with themes and images of primeval nature first encountered in the Introduction. It is through this technique, too, that the 'battered hut' washed up on the island is subtly yet unmistakably identified as Parasha's house, for this is precisely the wording used to describe it earlier in the poem (line 245). The leitmotif technique is also deployed to link different themes, so creating parallels between them, often for the purpose of contrast. Just one example of this is the repetition of phrases containing the verb 'think' or the noun 'thought' throughout the poem, linking Yevgeny, Peter and Alexander.

Of course, however 'musical' this particular technique may seem, it needs to be emphasised that Pushkin's use of it is almost certainly a case of analogy, rather than of direct influence. At that time examples of the leitmotif as we know it were fairly uncommon in music; its great exponent was an unknown twenty-year-old whose music dramas still lay in the future. Not that this really undermines our argument, for it has been suggested that Wagner's development of the musical leitmotif for dramatic purposes was in any case probably inspired not so much by musical precedents as by his reading of Aeschylus's Oresteia, where repeated phrasings are employed to similar effect.4 The leitmotif, then, would appear to inhabit a shadowy common ground shared by music and literature, ground which more research into its literary use before Wagner might do much to illuminate.

One further 'musical' technique may be identified as playing a part in the narration of The Bronze Horseman. It is a literary effect which has been compared to 
that of counterpoint in music. Theodore Ziolkowski, discussing Hermann Hesse's use of this technique in the novel Der Steppenwolf, calls it the principle of double perception' and traces it to the stories of E.T.A. Hoffmann. ${ }^{5}$ It may be defined as a mode of writing which all the time allows two differing interpretations of the events recounted, thus creating a continual interplay of the two simultaneous 'lines'. Ziolkowski shows that Hesse employed this technique in a deliberate attempt to recreate in his writing the effect of musical counterpoint.

There is a very similar deployment of the 'double perception' principle in The Bronze Horseman. Quite frequently in the poem, events can be given either a rational, positivist explanation, or a supernatural one, with no indication as to which is the 'correct' reading. (Interestingly enough, this is also true of Pushkin's story The Queen of Spades, written at Boldino at the same time as The Bronze Horseman.) On the face of it, The Bronze Horseman is a realistic story, set in the context of actual events (the flood) and a contemporary milieu. Pushkin gave it the subtitle Peterburgskaya povest', A St Petersburg Story (or Novella). His intention was no doubt to emphasise at the outset that this was to be a novella in verse, just as Eugene Onegin had been a novel in verse, and that consequently it would deal with the matter of real life. This is reinforced by the brief Preface stating that the story is based on the actual events of the 1824 flood, as well as by Pushkin's own footnotes with their contemporary references.

The 'double perception' arises when we consider the figure of Peter. On a purely realistic level he is of course dead at the time of the flood. And yet, as we have seen, his living presence seems to permeate the city. Pushkin hints in many ways that Peter's statue may be alive, but never actually oversteps the bounds of realism by stating explicitly that this is so; we as readers are free to accept either interpretation. A key passage here is the statue's pursuit of Yevgeny: does this really take place, or is it all a hallucination experienced by the deranged Yevgeny? Pushkin is careful not to exclude either possibility. Then there is the mysterious ferryman who takes Yevgeny across the Neva. Subtle hints imply his kinship with Charon in Greek mythology, ferrying the souls of the dead to the underworld (see above, note 19), but again it is equally possible to see him as an ordinary flesh-and-blood ferryman.

The double perception principle even has implications for the style of the poem. Although Pushkin rigorously observes regular metrical and rhyme schemes throughout, skilful use of enjambement and of deliberately non-poetic diction often 
creates the illusion - the aural illusion at least - of prose. A virtuoso example of this in the original is the closing section of the poem describing the little island where Yevgeny's body is eventually found. To listen to these lines read aloud by a competent performer is to listen to the sound of prose. Yet a glance at the printed page shows us that we are indeed listening to rhymed metrical verse. The effect, as with other examples of double perception, is of a rapid oscillation or switching between the two alternative interpretations. It is rather like those well-known optical illusions used to illustrate the principles of visual perception, which at first sight appear to represent a certain figure or shape, but then reveal a second, quite different one, after which both are seen simultaneously in rapid alternation.

Using these contrapuntal effects, together with the other techniques discussed (not to mention his sound painting, largely muted in translation), Pushkin has composed a work which may indeed be described as musical. However, it is important to finish with a caveat. The features of 'pure' music undeniably present in the poem are ultimately of secondary importance. As a poet, Pushkin by definition works with language, words, to which meaning inevitably attaches, as it does not to musical notes. And it is to the prime function of language - the conveyance of meaning - that his musical techniques are in the end subordinated. Unlike the composer of a symphony or sonata, who (unless he or she provides programme notes or other extra-musical clues) cannot assign meaning to the work's various themes, the poet can hardly avoid doing so. The interplay of themes in The Bronze Horseman may be musical in organisation, but it is literary and narrative in overall intent. As we have seen, the clash of order and chaos, of Peter and the elements, which would dominate in the value-free setting of a purely musical work, is in fact overshadowed by the significance given to Yevgeny, whose theme, peripheral perhaps in the musical scheme of things, is central to the poem as a work of literature.

As a creative artist, Pushkin has with some justice been compared to Mozart. Given his difficult political position vis-à-vis the tsarist authorities, it is worth pondering that the musical features of The Bronze Horseman may have been a deliberate attempt on his part to obscure with something of the ambiguity of music the explicit meaning of his text. If so, we might just as profitably compare him, mutatis mutandis, to a much later composer from his own country who in even more difficult circumstances resorted conversely to smuggling subversive meaning into the ambiguous musical argument of his works: Dmitry Shostakovich. 
1. A.D.P. Briggs, Alexander Pushkin. A Critical Study, London \& Canberra, 1983, p.123.

2. Ibid, p.129.

3. Ibid, p.130.

4. Hugh Lloyd-Jones, 'Wagner and the Greeks', The Wagner Compendium. A Guide to Wagner's Life and Music (ed. Barry Millington), London, 1992, p.159.

5. Theodore Ziolkowski, 'The Steppenwolf: A Sonata in Prose' (Chapter 9), The Novels of Hermann Hesse. A Study in Theme and Structure, Princeton, 1965, pp.178-228. 